\title{
On the Operations of the International Coffee Agreement
}

\section{Citation}

Bates, Robert H., and Da-Hsiang Donald Lien. 1985. On the operations of the International Coffee Agreement. International Organization 39(3): 553-559.

\section{Published Version}

http://dx.doi.org/10.1017/S0020818300019184

\section{Permanent link}

http://nrs.harvard.edu/urn-3:HUL.InstRepos:3224744

\section{Terms of Use}

This article was downloaded from Harvard University's DASH repository, and is made available under the terms and conditions applicable to Other Posted Material, as set forth at http:// nrs.harvard.edu/urn-3:HUL.InstRepos:dash.current.terms-of-use\#LAA

\section{Share Your Story}

The Harvard community has made this article openly available.

Please share how this access benefits you. Submit a story.

\section{Accessibility}




\section{On the operations of the International Coffee Agreement Robert H. Bates and Da-Hsiang Donald Lien}

Next to oil, coffee is the most valuable commodity traded in world markets; it is produced in the developing world and consumed within the developed nations. Moreover, the International Coffee Agreement is the major successful international commodity agreement. In this research note we analyze the allocation of quotas to export coffee in 1982 under the terms of the agreement. The way in which entitlements to export are allocated offers insights into significant features of the international political economy.

A study of the agreement is also important for analytical reasons. In recent years scholars of international relations have exported the rational choice perspective from the field of strategic studies and applied it in other domains. In particular, they have applied it to international agreements and the behavior of international organizations. ${ }^{1}$ We seek to advance this trend. We do so by modeling an international political institution - the International Coffee Organization (ICO) - and, by assuming rational behavior, analyzing the way in which the institution affects the international allocation of economic resources (in this instance, export entitlements).

\section{Background}

The International Coffee Organization was formed under the terms of the International Coffee Agreement, which was ratified in 1962. Its members

The research for this note was supported by the National Science Foundation (Grant no. SES 8216870); the Division of Humanities and Social Science, California Institute of Technology; and the Weingart Foundation. The note has benefited from comments by Philip Hoffman, Roderick Kiewiet, Keith Krehbiel, Kenneth Shepsle, Barry Weingast, Robert Keohane, Bela Balassa, Nathaniel Leff, Barry Ames, Cynthia McClintock, Michael Wallerstein, and Michael Westlake. Neither sponsors nor readers are responsible for errors.

1. The most notable recent application in strategic studies is Bruce Bueno de Mesquita, The War Trap (New Haven: Yale University Press, 1981). For extensions to areas of agreement and cooperation, see Robert Axelrod, The Evolution of Cooperation (New York: Basic, 1984). Coming closest to the approach explored here is Robert Keohane, After Hegemony (Princeton: Princeton University Press, 1984).

International Organization 39, 3, Summer $1985 \quad 0020-8183 / 85 / 030553-7 \quad \$ 1.50$

(C) 1985 by the Massachusetts Institute of Technology and the World Peace Foundation 
include the major consuming nations of Europe and North America, which account for 95 percent of annual consumption. Among producing nations only a handful of countries, each producing fewer than 100,000 bags per annum, remain outside the organization.

The agreement represents an attempt by producing and consuming nations to stabilize the price of coffee. The primary mechanism for price stabilization is the restriction of supplies to a level sufficient to maintain coffee prices within an agreed upon range (in $1984, \$ 1.20$ to $\$ 1.40$ per pound). The restrictions take the form of the imposition of quotas. To support the agreed upon price level, each producer agrees not to ship more than its assigned quota. Adherence to the quota is enforced through a system of stamps and certificates; the customs authorities of importing nations remit copies from each shipment to the headquarters of the organization, which in the case of overshipment calls for a reduction of the exporting country's quota. Producers that have fulfilled their quotas can make further sales on the nonquota market; prices on that market, however, currently average less than onehalf of those on the quota market. ${ }^{2}$

Frosts, insurrections, and other "acts of God" have from time to time forced prices above the defense range, thereby leading to the suspension of quantity restrictions. The most recent suspension of the terms of the agreement occurred following the Brazilian frost of 1975. Expanded production by other countries subsequently forced prices back down into the defense range, triggering a return to export restrictions. The question then arose: How was the burden of the restrictions to be allocated among producer nations? Here we analyze the apportioning of that burden by analyzing the fate of two proposals for quota allocations advanced after the reimposition of export restrictions. One, proposed in June 1982, failed to secure adoption by the member states; another was proposed in September 1982 and was ratified.

\section{The institution}

Formally, decisions within the organization having to do with the allocation of the quota are taken by vote. Consumer nations receive 1,000 votes; so too do producer nations; and a two-thirds majority of each "house" is required to establish a binding allocation. Each nation receives a "base" vote plus additional votes based upon its past performance as a shipper or importer

2. For background, see Bart S. Fisher, The International Coffee Agreement (New York: Praeger, 1972); Thomas Geer, An Oligopoly: The World Coffee Economy and Stabilization Schemes (New York: Dunellen, 1971); Stephen D. Krasner, "Manipulating International Commodity Markets," Public Policy 21, 4 (1973), pp. 493-513; J. W. F. Rowe, The World's Coffee with Special Reference to Control Schemes (Stanford: Food Research Institute, Stanford University, 1943); and Robert H. Bates and Da-Hsiang Donald Lien, "Coffee: An Essay on the Origins and Operations of Political Intervention in International Markets," unpublished. 
of coffee. Although not all decisions in fact come to a vote, interviews with officers of the organization and delegates to its meetings suggest that the anticipation of whether a measure would pass were it to be called to a vote helps to define whether it is a viable, as opposed to a "defeatable," proposal. The threat to use the rules to vote down proposals plays a significant role in negotiations.

The rules of the organization state that production quotas must be agreed to by a two-thirds majority of the votes of both the consumer and the producer members. Interviews reveal, however, that while producer and consumer nations do negotiate the overall price and quantity levels, consumer nations refuse to get involved in the subdividing of the overall quota into national quotas. American delegates noted that such involvement would cost a consumer nation more than it would gain; almost all of the producers are "our friends," they indicated, and rewarding one with an increased national quota would only antagonize all the others whose quotas were diminished as a result.

The rules of the organization allocate indicative quotas - that is, claims as to what a nation's quota might justifiably be. When calculating the quota entitlement of members upon the reimposition of the agreement, the rules (specifically, Article 30) were written to allow producing nations to base claims for a quota on their average exports for the period $1968 / 69$ to 1971 / 72 or for the period $1976 / 77$ to $1979 / 80$. Interviews made clear the reasons for this provision: in 1975 Brazil had been hit by a major frost and Colombia had expanded exports to take advantage of Brazil's misfortune. To secure the adherence of the two "giants," each had to be allowed to pick that basis for its quota which was most favorable.

The rules also allocate votes, on a weighted basis. Under Article 13 of the agreement, at the time of the quota proposals of June and September 1982the quotas that we shall analyze-votes were apportioned on the basis of the average volume of exports to importing members over the previous four years (i.e., $1976 / 77$ to $1979 / 80)^{3}$

These rules define an institution amenable to analysis by rational choice theory. They define a weighted majority voting game. Various approaches are available for predicting allocations within an institution possessing such a structure, but most are extremely difficult to apply to "real-world cases," for instance, where the number of actors is large. One solution concept for which an algorithm exists makes such an application possible: the Shapley value.

The Shapley value can be thought of as a measure of the power of player: to influence outcomes, given the rules of an institution. In an institution tha

3. For a variety of practical reasons we have had to assume that there is a one-year lag if revising the votes. Although this assumption may not be realistic, because of the stability $o$ market shares in the short run, these regression results should still apply even if we assume $\mathbf{n}_{1}$ lag in the allocation of votes. 
allows weighted votes, the Shapley value measures the ability of a player to use its share of votes to turn coalitions into electoral majorities. Its measure is the proportion of all possible coalitions that a player can convert into winning (i.e., majority) coalitions. The ability of the player to be pivotal in that sense defines the player's power. The Shapley value therefore defines as well the share of the payoffs that each player can expect to get, given its ability to exploit its strategic opportunities to make (or to refuse to make) coalitions into winning coalitions. It therefore suggests as well the allocational outcome of the game, in terms of the payoffs that should be expected to go to each player. Although we agree with many of the criticisms offered of the Shapley value, we have calculated the Owen approximation of it and sought to determine whether it allows us to account for the allocation of the coffee quota in $1982 .{ }^{4}$

\section{The analysis}

Our discussion implies the following model of the institution:
(1) $\mathrm{w}_{\mathrm{i}}=\mathrm{f}\left(\mathrm{p}_{1 \mathrm{i}}\right)$
by Article 13.
(2) $\mathrm{S}_{\mathrm{i}}=\mathrm{g}\left(\mathrm{w}_{\mathrm{i}}\right)$
by assumption of rational behavior.
(3) $\mathrm{q}_{\cdot_{\mathrm{i}}}=\mathbf{h}\left(\mathrm{S}_{\mathrm{i}}, \mathrm{p}_{2 \mathrm{i}}\right)$
by Article 30 and prediction.

where

$\mathrm{w}_{\mathrm{i}}=$ The proportion of votes held by producer $\mathrm{i}$.

$\mathrm{S}_{\mathrm{i}} \quad=$ The Shapley value of producer $\mathrm{i}$.

$\mathrm{q}_{\cdot_{\mathrm{i}}}=$ The quota assigned to producer $\mathrm{i}$. Two quota assignments were proposed: $\mathrm{q}_{1}$ and $\mathrm{q}_{2}$.

$\mathrm{q}_{\mathrm{li}}=$ The quota assigned to producer $\mathrm{i}$ under the June 1982 proposal. This proposal failed to secure adoption.

4. A useful introduction to the Shapley value, its problems, and other solution concepts is contained in William H. Riker and Peter C. Ordeshook, An Introduction to Positive Political Theory (Englewood Cliffs, N.J.: Prentice-Hall, 1973). For the approximation to the Shapley value employed here, see Guillermo Owen, Game Theory (New York: Academic, 1982). For our problem, the Shapley value for the i-th player is defined as:

$S_{i}=\sum_{i \in T} \frac{(t-1) !(N-t) !}{N !}$

where the summation is taken over all winning coalitions (i.e., a collection of members for which the summation of votes exceeds two-thirds of the total votes) $T$ such that $T-\{i\}$ is not winning. The number of elements in $\mathrm{T}$ is " $\mathrm{t}$ " and $\mathrm{N}$ is the number of players. A major problem with the Shapley value is that in calculating it all coalitions are treated as equally likely, which under many circumstances does not hold. 
$\mathrm{q}_{2 \mathrm{i}}=$ The quota assigned to producer $\mathrm{i}$ under the September 1982 proposal. This proposal was adopted.

$\mathrm{p}_{\mathrm{i \textrm {i }}}=$ Country i's average export share to importing members of the ICO, $1976 / 77$ to $1979 / 80$.

$\mathbf{p}_{1 \mathrm{i}}^{\prime}=$ Country i's average export share to importing members of the ICO, $1968 / 69$ to $1971 / 72$.

$\mathrm{p}_{2 \mathrm{i}}=$ The maximum of country i's average export share to importing members of the ICO for $1968 / 69$ to $1971 / 72\left(\mathrm{p}^{\prime}{ }_{1 \mathrm{i}}\right)$ or for the period $1976 / 77$ to $1979 / 80\left(\mathrm{p}_{1 \mathrm{i}}\right)$.

The three equations represent a model of the way in which the institution and its rules determine the allocation of the quota. ${ }^{5}$ The most direct test of this model of the operations of the coffee agreement is offered by coefficients in equation 3 , which, along with the other equations, can be estimated through two-stage least squares using the constant term, $p_{1}$ and $p_{2}$ as instrumental variables.

If rational behavior determines the impact of the rules of the International Coffee Organization upon allocations, then we can make two predictions. We would not expect the coefficient of the Shapley value to be significant in the case of the quota that failed $\left(\mathrm{q}_{1}\right)$; we would expect it to be significant in the case of the quota that passed $\left(\mathrm{q}_{2}\right)$. Given that the institution defines a weighted majority voting game, in other words, we would expect that a "passing" quota allocation would have to conform to the (Shapley) solution of the game. The results fulfill our expectations:

\begin{tabular}{|c|c|c|c|c|c|c|}
\hline $\mathrm{q}_{1}$ & $=$ & $\begin{array}{c}0.1354 \\
(1.0986)\end{array}$ & + & $\begin{array}{c}0.9410 p_{2} \\
(13.7564)\end{array}$ & + & $\begin{array}{c}0.0322 \mathrm{~S} \\
(0.4246)\end{array}$ \\
\hline $\mathbf{R}^{2}$ & $=$ & 0.9366 & & & & \\
\hline $\mathrm{q}_{2}$ & $=$ & $\begin{array}{c}-0.2279 \\
(-1.8765)\end{array}$ & + & $\begin{array}{c}0.8281 \mathrm{p}_{2} \\
(12.2902)\end{array}$ & + & $\begin{array}{c}0.2175 \mathrm{~S} \\
(2.9156)\end{array}$ \\
\hline $\mathrm{R}^{2}$ & $=$ & 0.9446 & & & & \\
\hline
\end{tabular}

The figures in parentheses are $\mathrm{t}$-statistics with seventeen degrees of freedom. ${ }^{6}$

5. One reader queried whether alternative specifications of the model should not be reported. We resist that invitation because our purpose here is to model the institution. The rules of the institution translate quite literally into the relationships specified in the model in the text. Reporting alternative specifications would, in other words, amount to modeling some other institution.

6 . We were asked to report the values of $R^{2}$ for these equations and have done so. It should be noted, however, that the values of ' $S$ ' are estimated within the system of simultaneous equations. They are therefore stochastic. The advantage of this procedure is that we thereby obtain estimates of the coefficients that are unbiased. But as a consequence it is difficult to argue that the right-hand side variables in these equations generate the element of "explained variance" employed in calculating the $\mathbf{R}^{2}$ statistic; they import elements of randomness as well. We therefore stress that in this case $\mathrm{R}^{2}$ does not communicate the same meaning as it does in single equation models. 
An additional result is of interest: we find that the Shapley value explains the allocation of the quota better than does the measure of raw votes or, in particular, the proportion of votes. The Shapley value bears the following relationship to the proportion of votes:

$$
\begin{aligned}
& \mathrm{S}=\underset{(26.6932)}{0.8227 \mathrm{w}}+\underset{(8.7515)}{0.0156 \mathrm{w}^{2}} \\
& \mathrm{R}^{2}=\underset{ }{0.9503}
\end{aligned}
$$

In this instance there are eighteen degrees of freedom. We have constrained the intercept to be zero because it makes little sense for a country possessing no votes to be able to convert coalitions that might otherwise remain voting minorities into majority winners. The sign and significance of the second coefficient suggests, as one would expect, that big powers are disproportionately advantaged by their ability to "pivot"-that is, to convert coalitions into majorities. But what is most interesting is what happens when this approximation to the Shapley value is substituted into the equation "predicting" $q_{2}$, that is, the successful quota.

$$
\mathrm{q}_{2}=\underset{(0.2019)}{0.0388}+\underset{(1.4702)}{0.0934 \mathrm{w}}+\underset{(2.2815)}{0.0086 \mathrm{w}^{2}}+\underset{(14.7572)}{0.8050 \mathrm{p}_{2}}
$$

$\mathrm{R}^{2}=0.9981$

Here there are sixteen degrees of freedom. The coefficient of $w^{2}$ still remains significant. This result suggests that it is not just votes which determine quotas, it is also the strategic advantages conferred by the requirement that votes be majorities - advantages that accrue disproportionately to the bigger powers (such as Brazil) and give them larger quotas than one would expect, given the distribution of votes. ${ }^{7}$

7. We can also estimate the system by GLS, which yields the following results:

$$
\begin{aligned}
& \text { (1) } \mathrm{w}=\frac{0.3783}{(2.3540)}+\underset{(44.1826)}{0.9242 \mathrm{p}_{1}} \\
& \text { (2) } \mathrm{S}=0.8399 \mathrm{w}+0.0146 \mathrm{w}^{2} \\
& \text { (29.8017) (9.0766) } \\
& \text { (3) } \mathrm{q}_{1}=0.1889+1.0234 \mathrm{p}_{2}-0.0610 \mathrm{~S} \\
& \begin{array}{lll}
(1.6557) \quad(18.1544) \quad(0.9837)
\end{array} \\
& \text { (4) } \mathrm{q}_{2}=-0.1986+0.8732 \mathrm{p}_{2}+0.1665 \mathrm{~S} \\
& \text { (1.6913) (15.0502) (2.6081) }
\end{aligned}
$$

Using two-stage least-square estimation, the first equation is

$w=0.3783+0.9242 \mathrm{p}_{\mathrm{l}}$, the same as obtained by GLS

$$
\text { (2.3540) (44.1826) }
$$

The two methods yield almost the same estimation and maintain the same qualitative results. In general, when error terms across equations are correlated, GLS will be biased. But for small sample cases, there are some situations in which GLS will dominate two-stage least squares. See Robert S. Mariano, "Analytical Small-Sample Distribution Theory in Econometrics: The Simultaneous-Equations Case,” International Economic Review 23 (October 1982), pp. 503-33. We therefore provide both estimates for comparison. 


\section{Conclusion}

We can summarize the economic impact of the political rules defined by the International Coffee Agreement by calculating, on the basis of the values of the parameters estimated above, the economic value of an additional vote. Assuming that coffee sells at $\$ 1.40$ a pound, that a bag contains 132 lbs., and that the world's exportable production is constrained to 58 million bags, then according to the above equation, an additional vote for a very small producer (say Kenya with 23 votes) would be worth about $\$ 168.5$ million per annum. For a "large" producer (say Brazil with 190 votes), an additional vote would be worth $\$ 566.1$ million per annum. Given the Third World's need for foreign exchange, the magnitude of these values suggests the economic significance of the political features of the coffee agreement.

How does our work fit in with other applications of rational choice analysis? Clearly it draws most directly from those forms applied to the analysis of voting and legislative behavior. ${ }^{8}$ These approaches can be employed in instances where there exist relatively orderly institutions that possess welldefined rules. It is not surprising, therefore, that they have most often been applied to the study of domestic politics rather than international relations. ${ }^{9}$

Other forms of rational choice theory apply more widely. Decision theory, for example, features in the work of Bruce Bueno de Mesquita. ${ }^{10}$ Other scholars, perhaps most notably Thomas Schelling, take note of the strategic interactions among nations; they therefore employ the theory of games. ${ }^{11}$ Still others, and in particular those who examine attempts by states to alter conditions in markets, draw upon models whose parentage lies more in economics than in politics - theories of imperfect competition, for example. ${ }^{12}$ Such approaches have strongly shaped some aspects of our research; in earlier, and as yet incomplete, papers we have employed models of monopolistic and oligopolistic behavior to account for the origins of the ICO. ${ }^{13}$ But we felt that once the International Coffee Organization was in place, with clearly specified rules and procedures, it was better analyzed employing models developed to study political institutions rather than unregulated markets. Controlling statistically for the effect of market power, we therefore employed the kinds of rational choice approaches most commonly applied in the study of elections and political assemblies.

8. For a review of much of this literature, see Riker and Ordeshook, Introduction to Positive Political Theory.

9. An exception would be the analysis of the United Nations. See, for example, ibid., pp. $170 \mathrm{ff}$.

10. Bueno de Mesquita, The War Trap.

11. Thomas Schelling, The Strategy of Conflict (New York: Oxford University Press, 1963).

12. See, for example, Keohane, After Hegemony.

13. See, for example, Bates and Lien, "Coffee." 